\title{
PENGETAHUAN DAN SUMBER INFORMASI BERHUBUNGAN DENGAN TINDAKAN PEMERIKSAAN PAYUDARA SENDIRI PADA SISWI SMA
}

\author{
Agustina Ningsi ${ }^{\bowtie}$, Sitti Mukarramah, Arika Cahyanti \\ Jurusan Kebidanan Poltekkes Kemenkes Makassar
}

\section{ARTICLE INFO \\ Article history}

Submitted : 2021-01-29

Revised : 2021-06-11

Accepted : 2021-07-31

\section{Keywords:}

Breast Self-Examination Knowledge

Resources

\section{Kata Kunci:}

Pengetahuan

SADARI

Sumber informasi

\begin{abstract}
Breast Self-Examination (BSE) is the development of a woman's concern for the condition of her own breasts. Breast cancer is a malignant tumor that grows in the breast tissue. The incidence of breast cancer reaches 42.1 per 100,000 population with an average death rate of 17 per 100,000 population. BSE on a regular basis is an important step for early detection of breast cancer. This study aims to determine the relationship between knowledge and sources of information about breast self-examination with early detection of breast cancer in female students of SMA Muhammadiyah 5 Tallo, Makassar City, using an analytic survey method and a Cross Sectional Design. The subjects of this study were young women in SMA Muhammadiyah 5 Tallo Makassar City with a population of 53 respondents who were taken by total sampling. Statistical analysis used in this study is Chi-Square statistic, with a confidence level of $a=0.05$. Based on the results of the study, it is known that the knowledge significance value is $\mathrm{P}$ $=0.001(\mathrm{p}<0.05)$ with a coefficient value $(\mathrm{Phi}=0.465)$, the source of information is $\mathrm{p}$ $=0.000(\mathrm{p}<0.05)$ with a coefficient value $(\mathrm{Phi}=0.635)$. So it can be concluded that there is a relationship between knowledge and sources of information about breast selfexamination at SMA Muhammadiyah 5 Tallo Makassar City. It is recommended for education providers and health workers to increase counseling about breast selfexamination.

Pemeriksaan Payudara Sendiri (SADARI) adalah pengembangan kepedulian seorang wanita terhadap kondisi payudaranya sendiri. Kanker payudara adalah tumor ganas yang tumbuh didalam jaringan payudara. Angka kejadian kanker payudara mencapai 42,1 per 100.000 penduduk dengan rata-rata kematian 17 per 100.000 penduduk. SADARI secara rutin merupakan langkah penting untuk mendeteksi dini kanker payudara. Penelitian ini bertujuan untuk mengetahui hubungan pengetahuan dan sumber informasi tentang pemeriksaan payudara sendiri dengan deteksi dini kanker payudara pada siswi SMA Muhammadiyah 5 Tallo Kota Makassar, menggunakan metode survey analitik dengan rancangan Cross Sectional Study. Subjek penelitian ini adalah remaja putri di SMA Muhammadiyah 5 Tallo Kota Makassar dengan populasi 53 responden yang diambil secara total sampling. Analisis statistik yang digunakan dalam penelitian ini adalah statistik Chi-Square, dengan tingkat kepercayaan $\mathrm{a}=0,05$. Berdasarkan hasil penelitian diketahui bahwa nilai signifikansi pengetahuan $\mathrm{P}=0,001(\mathrm{p}<0,05)$ dengan nilai koefisien $(P h i=0,465)$, sumber informasi $\mathrm{p}=0,000(\mathrm{p}<0,05)$ dengan nilai koefisien $(P h i=0,635)$. Sehingga dapat disimpulkan bahwa ada hubungan antara pengetahuan dan sumber informasi tentang pemeriksaan payudara sendiri di SMA Muhammadiyah 5 Tallo Kota Makassar. Disarankan bagi pihak penyelenggara pendidikan dan tenaga kesehatan hendaknya meningkatkan penyuluhan tentang pemeriksaan payudara sendiri.
\end{abstract}

Corresponding Author:

Agustina Ningsi

Jurusan Kebidanan Poltekkes Kemenkes Makassar

Telp. 081355878497

Email: agustina_ningsih@poltekkes-mks.ac.id

\section{PENDAHULUAN}

Pemeriksaan Payudara Sendiri (SADARI) adalah pengembangan kepedulian seorang wanita terhadap kondisi payudaranya sendiri. SADARI dilakukan untuk menetukan adanya benjolan abnormal pada payudara.
Kegiatan ini sangat sederhana dan dapat dilakukan oleh semua wanita yang sudah mengalami menstruasi tanpa perlu merasa malu kepada pemeriksa dan bisa juga dilakukan dengan sendirinya pada saat mandi atau pada saat berbaring. 
SADARI menjadi salah satu solusi untuk deteksi dini kanker payudara yang merupakan pembunuh nomor 1 untuk penduduk wanita yang diikuti oleh kanker serviks. Kanker payudara merupakan tumor ganas yang tumbuh didalam jaringan payudara. Setiap tahun lebih dari 185.000 wanita didiagnosa menderita kanker payudara. Insiden penyakit ini semakin meningkat di negara-negara maju. Sekitar 43.500 kematian akibat kanker payudara setiap tahunnya yang menjadikan penyakit ini sebagai penyebab kematian terbesar kedua setelah kanker paru pada wanita di Amerika Serikat (Kemenkes RI, 2015).

Bulan Oktober merupakan bulan peduli kanker payudara di seluruh dunia. Warna pink (merah muda) melambangkan sifat feminim digunakan sebagai lambang dukungan moral dan solidaritas terhadap penderita kanker payudara yang dicetuskan oleh Yayasan kanker payudara Susan G. Komen di Amerika pada tahun 1991. Di indonesia, kepedulian terhadap penderita kanker payudara didukung oleh Yayasan Kanker Payudara Indonesia (YKPI) yang berdiri sejak tahun 2003 sebagai organisasi untuk mengadakan kegiatan penyuluhan dan penanggulangan kanker payudara Indonesia dan memiliki visi dan misi untuk "Indonesia Bebas Kanker Payudara Stadium Lanjut Di Tahun 2030".

Kanker adalah penyakit akibat pertumbuhan tidak normal dari sel-sel jaringan tubuh yang berubah menjadi sel kanker. Dalam perkembangannya, sel-sel kanker ini dapat menyebar kebagian tubuh lainnya sehingga dapat menyebabkan kematian (Anies, 2018).

Berdasarkan data dari World Health Organization (WHO) diperkirakan sekitar 2,1 juta wanita yang terdiagnosis menderita kanker payudara dan setiap tahunnya diperkirakan $627.000(15 \%)$ wanita meninggal karena penyakit ini (WHO, 2018). Sedangkan data dari American Cancer Society, sekitar 252.710 wanita terdiagnosis kanker payudara invasive dan tiap tahunnya diperkirakan sekitar 40.610 wanita meninggal karena penyakit ini (American Cancer Society, 2017).

SADARI dengan rutin merabanya merupakan langkah penting untuk deteksi dini kanker payudara. Kebiasaan karena mudah, murah, cepat dan efektif untuk semakin mengenal dan menyadari jika terdapat suatu hal yang tidak normal pada payudara. Dengan melakukan deteksi dini dapat menekan angka kematian sebesar 20 - 30\%, dalam melakukan deteksi dini seperti SADARI diperlukan minat dan kesadaran akan pentingnya kesehatan untuk meningkatkan kualitas hidup untuk lebih baik (Sihite et al., 2019).

Data di Indonesia diperkirakan terdapat 100 penderita baru per 100.000 penduduk setiap tahunnya.Ini berarti dari jumlah 237 juta penduduk, ada sekitar 237.000 penderita kanker baru setiap tahunnya. Sejalan dengan itu, data empiris juga menunjukkan bahwa prevalensi kanker meningkat seiring dengan bertambahnya usia. Sekitar 2,2\% kematian semua umur disebabkan oleh kanker ganas. Prevalensi tumor/kanker di Indonesia adalah 1,4 per 1000 penduduk (Angrainy, 2017).

Pada tahun 2018 kasus kanker payudara di Kota Makassar mengalami kenaikan yaitu sebanyak 2,723 kasus dengan IVA positif sebanyak 40 kasus $(1,47 \%)$ (Dinas Kesehatan Provinsi Sulawesi Selatan, 2018). Berdasarkan hasil penelitian yang telah dilakukan oleh (Hadrianti, 2017) menunjukkan bahwa 65,3\% responden memiliki tingkat pengetahuan yang baik mengenai SADARI dan 100\% responden dikatakan tidak mampu dalam melakukan SADARI, namun 52,5 \% responden mampu melakukan langkah menggunakan tiga jari tangan kanan (jari telunjuk, tengah, dan manis) telusuri payudara.

Studi pendahuluan yang dilakukan pada tanggal 1 Desember 2018 di SMA Muhammadiyah 5 Tallo, dari 11 siswi yang di wawancarai hanya $2(20 \%)$ siswi yang tahu dan sudah melakukan SADARI sedangkan $9(80 \%)$ siswi tidak pernah mendengar dan melakukan SADARI. Berdasarkan uraian tersebut diatas tentang pentingnya Pemeriksaan Payudara Sendiri terhadap deteksi dini kanker payudara maka penulis tertarik untuk membatasi penelitian tentang hubungan pengetahuan dan sumber informasi dengan tindakan Pemeriksaan Payudara Sendiri pada Siswi SMA Muhammadiyah 5 Tallo Kota Makassar.

\section{METODE PENELITIAN \\ Jenis Penelitian}

Penelitian yang digunakan dalam penelitian ini adalah survey analitik dengan menggunakan rancangan Cross Sectional Study.

\section{Lokasi Penelitian}

Penelitian ini berlokasi di SMA Muhammadiyah 5 Tallo Kota Makassar. 


\section{Populasi dan Sampel}

Populasi dalam penelitian ini adalah semua siswi kelas XI dan XII SMA Muhammadiyah 5 Tallo Kota Makassar sebanyak 53 orang. Metode pengambilan sampel yang digunakan adalah total sampling dengan jumlah sampel sama dengan jumlah populasi yaitu 53 responden.

\section{Pengumpulan Data}

Alat yang digunakan dalam mengumpulkan data adalah kuesioner yang sudah diuji validitas dan realibilitasnya, berisi 30 pertanyaan yang berhubungan dengan deteksi dini kanker payudara yaitu, pengetahuan, sumber informasi dan SADARI.

\section{Pengolahan dan Analisis Data}

Data diolah dengan menggunakan komputer program SPSS, kemudian disajikan dalam tabel bentuk tabel dan narasi. Analisa data dalam bentuk analisis univariat dan bivariat.

\section{HASIL PENELITIAN}

Berdasarkan penelitian didapatkan hasil bahwa dari 53 responden di SMA Muhammadiyah 5 Tallo, remaja puteri yang mempunyai pengetahuan baik sebanyak 42 responden $(79,2 \%)$, sedangkan yang mempunyai pengetahuan yang kurang sebanyak 11 responden $(20,8 \%)$.

Tabel 1. Distribusi Frekuensi Responden menurut Pengetahuan Siswi di SMA Muhammadiyah 5 Tallo Kota Makassar

\begin{tabular}{ccc}
\hline Pengetahuan & $\begin{array}{c}\text { Frekuensi } \\
(\mathbf{N})\end{array}$ & $\begin{array}{c}\text { Persentase } \\
(\mathbf{\%})\end{array}$ \\
\hline Baik & 42 & 79,2 \\
Kurang & 11 & 20,8 \\
\hline Total & $\mathbf{5 3}$ & $\mathbf{1 0 0}$ \\
\hline \multicolumn{2}{l}{ Sumber: Data Primer Tahun 2019 }
\end{tabular}

Tabel 2 diperoleh data bahwa dari 53 responden, remaja puteri yang mendapatkan informasi secara langsnung tentang pemeriksaan payudara sendiri sebanyak 41 responden $(77,4 \%)$, dan remaja puteri yang tidak mendapatkan informasi secara tidak langsung tentang pemeriksaan payudara sendiri sebanyak 12 responden $(22,6 \%)$.

Berdasarkan tabel 3 di atas menunjukkan distribusi frekuensi responden menurut Pemeriksaan Payudara Sendiri (SADARI) dari 53 responden yang melakukan SADARI 40 responden $(75,5 \%)$ dan yang tidak melakukan SADARI 13 responden $(24,5 \%)$

\section{Tabel 2. Distribusi Frekuensi Responden menurut Sumber Informasi Siswi di SMA Muhammadiyah 5 Tallo Kota Makassar}

\begin{tabular}{|c|c|c|}
\hline $\begin{array}{c}\text { Sumber } \\
\text { Informasi }\end{array}$ & $\begin{array}{c}\text { Frekuensi } \\
(\mathbf{N})\end{array}$ & $\begin{array}{c}\text { Persentase } \\
(\%)\end{array}$ \\
\hline Langsung & 41 & 77,4 \\
\hline $\begin{array}{l}\text { Tidak } \\
\text { Langsung }\end{array}$ & 12 & 22,6 \\
\hline Total & 53 & 100 \\
\hline
\end{tabular}

Tabel 3. Distribusi Frekuensi Responden menurut Pemeriksaan Payudara Sendiri (SADARI) Siswi di SMA Muhammadiyah 5 Tallo Kota Makassar

\begin{tabular}{lcc}
\hline SADARI & $\begin{array}{c}\text { Frekuensi } \\
(\mathbf{N})\end{array}$ & $\begin{array}{c}\text { Persentase } \\
(\mathbf{\%})\end{array}$ \\
\hline Melakukan & 40 & 75,5 \\
Tidak & 13 & 24,5 \\
Melakukan & $\mathbf{5 3}$ & $\mathbf{1 0 0}$ \\
\hline \multicolumn{2}{l}{ Total } & $\mathbf{5 3}$
\end{tabular}

Tabel 4 menunjukkan dari 53 responden, siswi yang memiliki pengetahuan yang baik dan melakukan SADARI sebanyak 36 responden atau $(67,9 \%)$ dan yang tidak melaksanakan SADARI sebanyak 6 responden atau $(11,3 \%)$. Sedangkan siswi yang memiliki pengetahuan kurang sebanyak 4 responden atau $(7,5 \%)$ dan yang tidak melaksanakan SADARI sebanyak 7 responden atau $(13,3 \%)$. Berdasarkan hasil analisis statistik yang menggunakan SPSS versi 20 dengan uji Chisquare didapatkan nilai $p=0,001(<a=0,05)$ maka Ha diterima artinya terdapat hubungan antara pengetahuan tentang periksa payudara sendiri.

Dari 53 responden, sebanyak 37 responden atau $(69,8 \%)$ siswi yang mendapat informasi secara langsung tentang SADARI dan yang tidak melaksanakan SADARI sebanyak 4 responden atau $(7,5 \%)$. Sedangkan secara tidak langsung mendapatkan informasi tentang 
SADARI sebanyak 3 responden atau $(5,7 \%)$ dan yang tidak melaksanakan SADARI sebanyak 9 responden atau $(17,0 \%)$. Berdasarkan hasil analisis statistik yang menggunakan SPSS versi 20 dengan uji Chi- square didapatkan nilai $p=0,000(<a=0,05)$ maka Ha diterima artinya terdapat hubungan antara pengetahuan tentang pemeriksaan payudara sendiri.

Tabel 4. Analisis Hubungan Pengetahuan dan Sumber Informasi dengan Tindakan Pemeriksaan Payudara Sendiri pada Siswi SMA Muhammadiyah 5 Tallo Kota Makassar

\begin{tabular}{|c|c|c|c|c|c|c|c|}
\hline \multirow{3}{*}{$\begin{array}{c}\text { Variabel } \\
\text { Penelitian }\end{array}$} & \multicolumn{4}{|c|}{ Periksa Payudara Sendiri } & \multirow{2}{*}{\multicolumn{2}{|c|}{ Jumlah }} & \multirow{3}{*}{ P Value } \\
\hline & \multicolumn{2}{|c|}{ Melaksanakan } & \multicolumn{2}{|c|}{$\begin{array}{c}\text { Tidak } \\
\text { Melaksanakan }\end{array}$} & & & \\
\hline & $\mathbf{n}$ & $\%$ & $\mathbf{n}$ & $\%$ & $\mathbf{N}$ & $\%$ & \\
\hline \multicolumn{8}{|c|}{ Pengetahuan Siswi } \\
\hline Baik & 36 & 67,9 & 6 & 11,3 & 42 & 79,2 & \multirow{3}{*}{0,001} \\
\hline Kurang & 4 & 7,5 & 7 & 13,2 & 11 & 20,8 & \\
\hline Jumlah & 40 & 75,4 & 13 & 24,5 & 53 & 100 & \\
\hline \multicolumn{8}{|c|}{ Sumber Informasi } \\
\hline Langsung & 37 & 69,8 & 4 & 7,5 & 41 & 77,3 & \multirow{3}{*}{0,000} \\
\hline Tidak Lansung & 3 & 5,7 & 9 & 17,0 & 12 & 22,7 & \\
\hline Jumlah & 40 & 75,4 & 13 & 24,5 & 53 & 100 & \\
\hline
\end{tabular}

\section{PEMBAHASAN}

Hubungan Pengetahuan dengan Tindakan Pemeriksaan Payudara Sendiri pada Siswi SMA

Pengetahuan adalah suatu hasil dari rasa keingintahuan melalui proses sensoris, terutama pada mata dan telinga terhadap objek tertentu. Pengetahuan merupakan domain yang penting dalam terbentuknya perilaku terbuka atau open behavior (Donsu, 2017).

Berdasarkan hasil penelitian dari 53 responden mayoritas memiliki pengetahuan dan melakukan SADARI sendiri dibandingkan dengan yang tidak tahu dan tidak melakukan SADARI. Berdasarkan hasil analisis statistik uji Chi-Square sehingga diperoleh nilai $\mathrm{p}=0,01$ lebih kecil dari $a=0,05$, sehingga Ha diterima dan Ho ditolak. Sehingga dapat dikatakan bahwa ada hubungan pengetahuan tentang pentingnya SADARI di SMA Muhammadiyah 5 Tallo Kota Makassar Tahun 2019.

Hasil penelitian ini sejalan engan penelitian yang dilakukan oleh (Puspita, 2016) yang menyatakan bahwa ada hubungan pengetahuan tentang SADARI dengan tindakan SADARI pada siswi fakultas non kesehatan di Universitas Hasanuddin Makassar. Hasil uji statistik dengan Chi-Square menunjukkan bahwa probabilitas $=0,000<a=0,05$ berarti
Ho ditolak artinya ada hubungan pengetahuan tentang SADARI dengan tindakan SADARI pada siswi fakultas non kesehatan di Universitas Hasanuddin Makassar.

Hal ini sejalan dengan teori (Notoatmodjo, 2010) yang menyatakan bahwa tingginya pengetahuan akan berdampak pada proses perubahan perilaku yang akan dilakukan sehubungan dengan permasalahan yang dihadapinya, seseorang yang memiliki pengetahuan yang baik dalam suatu hal akan mudah menerima perilaku yang lebih baik, sebaliknya seseorang yang memiliki pengetahuan yang rendah akan sulit menerima perilaku baru dengan baik.

\section{Hubungan Sumber Informasi dengan Tindakan Pemeriksaan Payudara Sendiri pada Siswi SMA}

Sumber informasi adalah sesuatu yang menjadi perantara dalam menyampaikan informasi, merangsang pikiran dan kemampuan informasi yang diperoleh (Notoatmodjo, 2014). Berdasarkan hasil penelitian menunjukkan bahwa dari 53 responden mayoritas mendapatkan informasi secara langsung dan dapat melaksanakan SADARI dibandingkan dengan yang tidak mendapat informasi dan tidak dapat melaksanakan SADARI. 
Berdasarkan hasil analisis statistik uji Chi-Square sehingga diperoleh nilai $\mathrm{p}=0,00$ lebih kecil dari $a=0,05$, sehingga Ha diterima dan Ho ditolak. Sehingga dapat dikatakan bahwa ada hubungan sumber informasi tentang pentingnya SADARI di SMA Muhammadiyah 5 Tallo Kota Makassar Tahun 2019.

Hasil penelitian ini sejalan dengan penelitian yang dilakukan oleh (Sari et al., 2015) di SMK Negeri 8 Medan yang menyatakan bahwa ada hubungan antara sumber informasi dengan tindakan SADARI karena $p$ value $(0,000)<$ dari $a=0,05$. Setelah dilakukan analisis multivariat dengan uji regresi logistik ternyata sumber informasi paling dominan mempengaruhi tindakan SADARI dengan nilai $\mathrm{p}=0,000<0,05$.

Sebuah sumber informasi sangat berpengaruh terhadap responden, karena dengan adanya informasi yang baik akan memberi pengetahuan terhadap responden dan bisa merubah sikap responden akan tetapi tidak terdapat hubungan yang signifikan antara sumber informasi dan sikap SADARI.

\section{KESIMPULAN DAN SARAN}

Berdasarkan hasil penelitian yang dilakukan di SMA Muhammadiyah 5 Tallo Kota Makassar dapat ditarik kesimpulan bahwa pengetahuan dan sumber informasi memiliki hubungan dengan tindakan SADARI. Petugas kesehatan diharapkan untuk melakukan penyuluhan kesehatan kepada remaja mengenai tujuan, waktu pelaksanaan dan cara melakukan SADARI secara langsung atau melalui media cetak (poster \& pamflet) sehingga pengetahuan remaja akan meningkat dan dapat mendeteksi secara dini benjolan pada payudaranya yang dapat mengarah kepada kanker payudara.

\section{DAFTAR PUSTAKA}

American Cancer Society. (2017). Cancer Facts \& Figures 2016. Www.Cancer.Org. https://www.cancer. org/research/cancer- facts- statistics/allcancer-facts-figures/cancer-facts-figures2016.html.

Angrainy, R. (2017). Hubungan Pengetahuan, Sikap Tentang Sadari Dalam Mendeteksi Dini Kanker Payudara Pada Remaja. Jurnal Endurance, 2(2), 232. https://doi.org/10.22216/jen.v2i2.1766.

Anies. (2018). Penyakit Degeneratif. Ar-Ruzz Media.

Dinas Kesehatan Provinsi Sulawesi Selatan. (2018). Profil Kesehatan Provinsi Sulawesi Selatan tahun 2017.

Donsu, J. D. T. (2017). Psikologi Keperawatan: Aspek-Aspek Psikologi, Konsep Dasar Psikologi, Teori Perilaku Manusia (Cet. 1). Pustaka Baru Press.

Hadrianti, S. (2017). Gambaran Pengetahuan dan Kemampuan Melakukan Pemeriksaan Payudara Sendiri (SADARI) pada Ibu Rumah Tangga di Wilayah Kerja Puskesmas Pallangga Kabupaten Gowa [Universitas Hasanuddin Makassar]. http://digilib. unhas.ac.id/opac/detail-opac?id=37831.

Kemenkes RI. (2015). Profil Kesehatan Indonesia tahun 2014. Kemenkes RI.

Notoatmodjo, S. (2010). Ilmu Perilaku Kesehatan. Rineka Cipta.

Notoatmodjo, S. (2014). Promosi Kesehatan dan Perilaku Kesehatan. Rineka Cipta.

Puspita, N. D. (2016). Faktor yang Berhubungan dengan Perilaku SADARI pada Mahasiswi Fakultas Non Kesehatan di Universitas Hasanuddin. Universitas Hasanuddin Makassar.

Sari, Y., Lubis, N. L., \& Syahrial, E. (2015). Determinan Perilaku SADARI Remaja Putri dalam Upaya Deteksi Dini Kanker Payudara di SMK Negeri 8 Medan Tahun 2014. Kebijakan, Promosi Kesehatan Dan Biostatistik (Online), 634. https://www.neliti.com/publications/1435 6/determinan-perilaku- sadari-remajaputri-dalam-upaya-deteksi-dini- kankerpayudara.

Sihite, E. D. O., Nurchayati, S., \& Hasneli, Y. (2019). Gambaran Tingkat Pengetahuan tentang Kanker Payudara dan Perilaku Periksa Payudara Sendiri (SADARI). Jurnal Ners Indonesia, 10(1), 8-20. https://doi.org/10.31258/jni.10.1.8-20.

WHO. (2018). Cancer Prevention Diagnosis Skrining Breast Cancer en. Www.Who.Int. http://www.who. int/ cancer/prevention/diagnosis-skring/breast cancer/en/. 